\title{
Income inequality and financialization: A not so straightforward relationship
}

Constantinos Alexiou ${ }^{\mathrm{a}}$, Emmanouil Trachanas ${ }^{\mathrm{b}}$, and Sofoklis Vogiazas ${ }^{\mathrm{c}, *}$

\author{
${ }^{a}$ Cranfield School of Management, Cranfield University, Cranfield, UK \\ ${ }^{\mathrm{b}}$ Oxford Brookes Business School, Oxford Brookes University, Oxford, UK \\ 'Black Sea Trade and Development Bank, Thessaloniki, Greece. *Corresponding author: E- \\ mail: svogiazas@bstdb.org
}

\section{Structured abstract}

Purpose - We explore the impact of financialization on income inequality for a panel of 19 OECD countries over the period 2000-2017. We control for the effect of banking crises, credit market regulation, and globalization, among other factors.

Design/methodology/approach - We use three proxies for income inequality and four proxies for financialization. We employ a panel fixed effects approach using Driscoll and Kraay's (1998) nonparametric covariance matrix estimator which produces standard errors that are robust to general forms of cross-sectional dependence.

Findings - We provide evidence which to a great extent supports the view that the process of financialization has increased income inequality. In the disposable Gini specifications, two out of the four financialization measures are found to significantly contribute to rising inequality whilst in the specification with the market income Gini coefficient, three out of the four financialization proxies appear to adversely affect inequality. In the specification with the Gini coefficient based on manufacturing pay, the evidence is weak. Furthermore, trade unions appear to play a significant role in reducing inequality in two out of the three Gini specifications while the effect of credit market regulation is rather ambiguous.

Originality - Our findings suggest a positive relationship between financialization and income inequality, however, the results depend on the proxies used to measure financialization and income inequality. We conclude that the process of financialization in triggering income inequality is complex and merits additional research.

Keywords Income inequality, Financialization, Credit regulation, Unionization 


\section{Introduction}

Broadly speaking, the term financialization describes a specific process over a certain period during which capitalism has evolved into a system dominated by the rise of finance as a key determinant of both economic and social activities. According to Epstein (2005, p. 3), financialization entails "the increasing role of financial motives, financial markets, financial actors and financial institutions in the operation of the domestic and international economies". Alternatively, the term financialization describes the development of financial capitalism where the debt-to-equity ratios increase and financial services account for an ever-increasing share of income in an economy relative to other sectors.

The global 2008 financial crisis, which brings to memory the old debate on the link between economic downturns and inequality, is thought to be nurtured by a deregulated economic environment that emerged in the 1980s (Prasad, 2005). Through massive transfers of funds to the financial sector from other economic sectors, including taxpayers (TomaskovicDevey and Lin, 2011), financialization seems to be associated with growing income inequality, especially in the most developed economies. The frequent occurrence of financial crises in developed economies is thought to be triggered by the inherent contradictions and volatility permeating deregulated and highly leveraged financial markets, leading to disruptions in income distribution (Tomaskovic-Devey et al., 2015). Further evidence on the relationship between bank regulation and income suggests that changes in institutions and deregulation of various industries significantly impact wage inequality (Fortin and Lemieux, 1997). Despite the emerging evidence on the impact of financialization on rising income inequality (see for instance, Zalewski and Whalen, 2010; Assa, 2012; Kus, 2012; Van Arnum and Naples, 2013), there are still open questions about this relationship and several forces at play that require additional research in the foreseeable future (Epstein, 2015).

The concept of financialization is multifaceted; it might refer to the activities of the financial sector, the increase in the size of the financial sector, or even the increasing use of financial instruments by non-financial corporations. Undoubtedly, financialization is thought to have contributed to increasing income inequality through different channels, including macroeconomic policies. For instance, sustained quantitative easing has resulted in zero-lowbound or even negative interest rates, hence fuelling a potential formation of bubbles. At the same time, the implementation of austerity policies has adversely affected those in need of government assistance. When measured through its impact on income inequality, financialization can also be explained through the marketization lens, as this is reflected by the sustained increase in the social activity that is currently devoted to securities trading in the 
financial markets. As De Vita and Luo (2020, p. 2) eloquently put it, the channels through which different financialization dimensions can affect income inequality "range from a weakening of certain policies and institutions that help keep income disparity in check to a shift from the traditional 'retain and reinvest' policy of nonfinancial firms to a new profit model that emphasizes prioritizing shareholders' dividends that feed the income of the wealthy".

Furthermore, the way capitalism has evolved as an economic system has led to a shift in power relations between capital and labor. As a result, income distribution has shifted sharply in favor of capital, leaving working-class households struggling to maintain existing consumption patterns whilst at the same time dampening domestic demand. The already established but inconclusive evidence on socio-economic channels through which financial accumulation affect income inequality has provided the impetus to delve deeper into the financialization-inequality nexus literature.

Given the above, this paper attempts to contribute to the discussion on the financialization-inequality nexus by using three different proxies for inequality and four different proxies for financialization whilst at the same time controlling inter alia for globalization, credit regulation, and banking crises. In this direction, we generate novel evidence by employing an econometric technique which unlike those used in previous empirical studies addresses several estimation issues such as the one of cross-sectional dependence, hence providing more robust and reliable estimates. Using a panel data methodology, we identify the linkages between the dimensions of financialization and income inequality in 19 developed economies over the period 2000 to 2017. The yielding evidence suggests that financialization has a positive effect on income inequality when we consider disposable income and market income Gini coefficient measures. However, when a Gini coefficient based on manufacturing pay is considered, three out of the four proxies used to capture financialization are found to be insignificant. The effect of credit regulation is ambiguous whilst trade unions appear to be playing an influential role in alleviating household market income inequality.

The rest of the paper is organized as follows: Section 2 elaborates on the theoretical underpinnings of financialization and its relationship with income inequality. Section 3 discusses the dataset and the empirical framework employed to arrive at the results presented in Section 4. Section 5 presents some closing remarks and policy recommendations. 


\section{Background to financialization}

Financialization is a relatively new term, which refers to the increase in size and importance of a country's financial sector relative to its overall economy. The most-cited definition from

Epstein (2005) states: "financialization means the increasing role of financial motives, financial markets, financial actors and financial institutions in the operation of the domestic and international economies". The institutional setting of financialization has been largely framed in an environment dominated by deregulated financial and labor markets (Sawyer, 2017). The nature of economic liberalization that has emerged across many advanced economies has paved the way for the financialization of capitalism from its predecessor, industrial capitalism.

Several scholars have attempted to provide insightful accounts concerning the impact of financialization on economic activity. Possibly the most dominant trend that has provided the lead for others to follow is the one proposed by Hilferding (1981). According to Hilferding, the rise to power of a class of finance capitalists provides the platform upon which their influence and that of financial markets on economic outcomes and policies can be critically analyzed.

The financialization of industrial and commercial capital has been evident since the 1980s with the banking sector predominantly seeking profits in financial markets whilst households were drawn into complex financial transactions to boost their borrowing ability or their net worth. The implication of this development is of paramount importance as the activities of the financial sector have shifted away from the traditional intermediating role of "linking savings to investments towards the financing of consumer debt, the expansion of financial assets and financial liabilities, and the trading of existing financial assets" (Sawyer, 2015, p.1). Although it can be argued that industrial and financial capital developed a symbiotic relationship in advanced economic systems, there is evidence that the conflict between industrial and financial capital has negatively affected real economic activity. In this context, Argitis and Pitelis (2001, 2008) and Alexiou and Nellis (2016), argue that the financialization of large corporations has harmed their long-term investment strategies with the distribution of profits between industry and finance playing an instrumental role in affecting capital accumulation. In the same spirit, Minsky $(1982,1986)$ argues that the financial practices of the non-financial corporate sector can have a significant impact on an economy that is inherently fragile and unstable, whilst Harcourt and Sardoni (1995) sustain that existing imbalances between finance capital and industrial capital can be legitimate sources of market volatility, hence resulting in dwindling private sector liquidity which in turn stifles investment (Davidson, 1978). 
It is also worth noting that financial capitalism is closely associated with the behavior of rentiers, private bankers, currency speculators, portfolio investors as well as central bankers and their business activities, i.e. speculation in money and capital markets. Crotty and Epstein (1996) and Crotty (2009) argue that as these groups grow in importance the more likely it is for financial capitalists to control both industrial and commercial capital. Epstein (2001) and Argitis and Pitelis (2001) studied the impact of financial capital on income distribution and articulately delineated the role of tight monetary policy and inflation targeting during the process of financialization.

Arguably, the perception that all financial activities add value to an economy's GDP or create employment opportunities might be misleading. The notion that highly skilled personnel working in banks and financial innovation have positive spillover effects on society per se should be carefully evaluated. Alexiou and Nellis (2016, p. 155) argue that "financial innovation and advances in information and communications technologies have facilitated capital mobility but without any explicit policy directives by governments, capital controls would have prevented the globalization of finance and the increasing integration of national financial markets". What is even more extraordinary about financial capital vis-à-vis industrial capital is its exploitative nature since profits can be extracted indiscriminately across all levels of money income. Financial profit constitutes a significant percentage of total profit in many advanced economies (ILO, 2009).

According to Philippon (2007), the time evolution of the financial sector's share of total US GDP from 1860 onwards is indicative of the dominance of financial capital. In particular, the financial sector's share of US GDP has grown from about $2 \%$ in the late 19th century to $4.9 \%$ in 1980 , and further to $8.3 \%$ in 2007 without showing any trends of mitigation as one would expect in the aftermath of the global financial crisis. As Orhangazi (2008, p. 35) further explains, "when we look at the US economy in the late 19th century, we see a period characterized by a large and powerful financial sector accompanied by the dominance of monopolies and oligopolies". Alexiou and Nellis (2016) conclude that financialization has had a profound impact on the entire system of economic and institutional relations between finance, industry, and labor, between global finance and national economies, and between states and markets in a rapidly changing economic environment.

\section{Financialization and income inequality}

Undoubtedly, the process of financialization that has been gathering momentum since the 1970s, appears to be the driving force behind large financial gains registered in the balance 
sheets of financial institutions. Despite the expansionary effect that financialization might have had in generating value-added and employment in the financial sector (see Assa, 2012), there is evidence to suggest however that the rapid growth in financial activities, particularly in nonfinancial industries, has had negative distributional effects (Cecchetti and Kharroubi, 2012; Tomaskovic-Devey et al., 2015).

On the empirical front, the evidence regarding the impact of financialization on income inequality has been rather mixed. More specifically, Greenwood and Jovanovic (1990) and Claessens and Perotti (2007), suggest that the benefits of more efficient financial markets will only be harnessed by the already wealthy individuals and established firms, whilst Beck et al. (2007) in a study on the impact of financial development on inequality for 72 countries spanning the period 1960-2005 find that financial development reduces income inequality. Furthermore, Delis et al. (2014) find that financial liberalization has a negative and significant effect on income which turns insignificant when low-income countries are considered. In the same spirit, Agnello et al. (2012) find that financial reforms negatively affect income inequality, but this effect is contingent upon the nature of the liberalization policies implemented. In a different study that gauges the impact of globalization on income inequality, Jaumotte et al. (2013) find that financial globalization might explain income dispersion whereas trade globalization reduces income inequality.

Alexiou and Nellis (2016) suggest that the credit expansion that has followed the deregulation of the financial sector has to a large extent, through mainly speculative activity, contributed to the inherently unstable financial system that led-up to the financial crisis in 2008 . Deregulation initiatives in the USA for instances such as the repeal of the Glass-Steagall Act, the Financial Services Modernization Act, and the Federal Deposit Insurance Corporation, accelerated bank mergers hence promulgating the too-big-to-fail argument, empowered banks to speculate using their customers' deposits, and provided bail out insurance to failing banks (Krippner, 2011; Wright and Rogers, 2015). In this context, Lin (2016) suggests that credit expansion indirectly through the channel of accumulation of corporate debt adversely affects long-term investment activity and hence employment. As growth in the nonfinancial sector dwindles and profitability in the financial sector increases, the incessant pressure on incomes of nonfinancial workers leads to increases in income inequality (Evans, 2003; TomaskovicDevey and Lin, 2011; Tomaskovic-Devey et al., 2015). Among the recent studies, Knon and Roberts (2015) using a panel data set of 18 advanced industrial economies in the period 19882008 found that the interactions of financialization with measures of the new economy are positively correlated with income inequality. 
On the distributional aspects of financialization, Dünhaupt (2013, p. 2) argues that "the process of financialization can roughly be described as the increasing importance of the financial sector which has an impact on the distribution between wages and profits on the one hand, and retained earnings and financial income in the form of dividends and interests on the other hand". The rise in continental European labor's shares of income in the 1970s was to a great extent attributed to institutional reforms and real wages increases above labor productivity (Bertoli and Farina, 2007). The response of firms was to restore profit shares by substituting labor demand with an increase in capital-intensive production (Blanchard, 1997). In the same line of argument, Lin and Tomaskovic-Devey (2013), argue that financialization drives wages for financial employees whilst limits wage growth for nonfinancial workers. They also find that the surge of financial income in the US over the period 1970 to 2008 adversely affected the labor share of income, whilst Alvarez (2015) finds that increased dependence on financial profits drives the wage share in nonfinancial firms down over the period 2004 to 2013. Further corroborating evidence is provided by Köhler et al. (2018) confirming the negative effects of financialization on the wage share of labor.

In another recent study, Sawyer (2017) argues that financialization has been associated with the 'rise of the push' for the maximization of shareholder value. In this process, financialization is viewed in terms of increasing shareholder power relative to management and workers, and a higher rate of return to rentiers on bond and equity holdings all of which hurt firms' real investment. At the same time, the deepening of financialization is associated with the build-up of financial risk (Szopa, 2017) thus, affecting the stability of the entire economy.

Additionally, Van Arnum and Naples (2013) studied the relationship between financial sector growth and income inequality and suggested that financialization has adversely affected employment creation and minimum wage and exacerbated income inequality as well (Van Arnum and Naples, 2013). Using panel data for 20 OECD countries, Kus (2012) provided evidence according to which financialization, as proxied by three different ratios (i.e. stock traded, bank profitability, and securities under bank assets), has a positive association with income inequality whilst union density is a key variable through which this effect is mediated.

First-generation studies on the impact of unionization on wage inequality concluded that declining unionization explained around 15 to $20 \%$ of the increase in wage inequality in the 1980s (Card, 1992; Gosling and Machin, 1995). Second-generation studies however using more advanced econometric methodologies provided a more complete picture of the effect of unions in wage inequality. In particular, DiNardo and Lemieux (1997) implementing a re- 
weighting technique, found that increased unionization in 1981 reduced the variance of male wages by 6 percent in the US and 10 percent in Canada, whereas in 1988 the corresponding estimates were 3 percent in the US and 13 percent in Canada, respectively. In other words, changing unionization in the USA has caused wage inequality whereas in the case of Canada the causal relationship runs in the opposite direction. On the same wavelength, Gordon (2012) argues that declining unionization has been the culprit behind a one-third increase in income inequality in the 1980s and 1990s.

\section{Data and methodology}

We study the determinants of the relationship between inequality and financialization for 19 advanced economies: Australia, Austria, Belgium, Canada, Denmark, Finland, France, Germany, Italy, Japan, Korea, Netherlands, New Zealand, Norway, Spain, Sweden, Switzerland, United Kingdom, USA. We estimate unbalanced panels with annual data spanning the period 2000-2017. Our effort to use more countries and a longer time period was hampered by data availability, however, our dataset effectively captures key characteristics of developed capitalist economies in the recent era, i.e. the diminished role of the State, privatization, increased trade, and deregulation.

In our estimated models, income inequality is measured by the Gini coefficient and for comparison purposes, we employ three alternatives: a Gini index of inequality in equivalized household disposable income (post-tax, post-transfer) and a Gini index of inequality in equivalized household market income (pre-tax and pre-transfer) both retrieved from the Standardized World Income Inequality Database (SWIID) which was developed by Solt (2020), and a Gini index of inequality developed by Galbraith and Kum (2005) which is based on manufacturing pay data but does not include other income sources such as transfers.

All estimated models include a set of independent variables, the nature of which reflects inter alia the business cycle, economic and financial stability, and credit regulation. In this context, it is suggested that potential determinants of inequality, includes amongst others, unemployment, productivity, trade, GDP per capita to capture the level of economic development, FDI net inflows, union density, $R \& D$ expenditure, inflation as a measure of economic stability, and education to capture the level of human capital. We also include a dummy variable to account for banking crises which was developed by Laeven and Valencia (2013) and a credit market regulations index to capture regulatory restraints that limit the freedom of exchange in credit markets. 
For each of the three Gini measures of income inequality, we estimate four models (Models 1 to 4 ) all of which include the control variables described above and additional key proxy variables for financialization. Model 1 includes the percentage of deposit money bank assets to deposit money bank assets and central bank assets (depositassets), Model 2 uses the private credit by deposit money banks as a percentage of GDP (privatecredit), Model 3 includes bank deposits as a percentage of GDP (bankdeposits), and Model 4 includes domestic credit to private sector as a percentage of GDP (domcredpri). Table 1 provides detailed descriptions of the variables and their sources while Table 2 presents the summary statistics.

\section{[Tables 1 and 2 about here]}

It is well established that spatial or spillover effects can lead to cross-sectional dependence and, if ignored could result in biased statistical inference. We implemented the Pesaran (2015) cross-sectional dependence test where the rejection of the null hypothesis indicates the presence of strong dependency. The results are presented in the Appendix and suggest that innovations to the variables are strongly cross-sectional dependent. To account for this, we employ a panel fixed-effects approach using the Driscoll and Kraay's (1998) nonparametric covariance matrix estimator which produces heteroscedasticity- and autocorrelation-consistent standard errors that are robust to general forms of cross-sectional dependence.

\section{Empirical results and discussion}

The panel estimation results for the three different dependent variables employed are presented in Tables 3 to 5. In Table 3, where income inequality is proxied by the Gini coefficient based on household disposable income, we note that two out of the four proxies that purport to gauge the impact of financialization on inequality are found to be statistically significant and positive, hence supporting the view that the increasing role of financial markets might harm the distribution of income as also suggested by Cecchetti and Kharroubi (2012), Jauch and Watzka (2015) and Tomaskovic-Devey et al. (2015), among others. In line with Jauch and Watzka (2015), it seems that excessive finance leads to the appearance of rent-seeking in financial markets and its appropriation by a minority that effectively leads to increased income inequalities.

\section{[Table 3 about here]}

The results further suggest the highly significant effect of unemployment, productivity, education, and credit market regulation in triggering inequality, thus impacting negatively societal cohesion. In particular, education is found to be significant in three out of four 
estimated models suggesting that it can potentially amplify income inequality, and although this might appear surprising it is in line with Willen et al. $(2004$, p. 1) who suggest that education affordability drives down the wage of unskilled workers and raises the skill premium. The impact of banking crises is found to be rather ambiguous with a significant positive impact in two out of four models while credit market regulation is positive and highly significant in all specifications. This last finding indicates that more intense regulation increases household disposable income inequality as "entrepreneurs at the bottom rungs of the income distribution may have relatively greater difficulty surmounting costly barriers to entry" (McLaughlin and Stanley, 2016, p.2). Finally, the fact that productivity appears to positively affect income inequality might be effectively explained if we consider the uneven growth of productivity across various economies. Top firms' earnings exhibiting increasingly skewed returns as well as wage dispersion between firms, which reflects diverging rates of productivity growth, can to a certain extent explain the observed increase in income inequality (Furman and Orszag, 2018). On top of this, financialization may have generated incentives for short-term profit maximization to the detriment of sufficiently channeling resources to more productive activities (Ramos, 2016).

Turning our attention to the Gini proxy based on market income (Table 4), the yielded evidence suggests that three of the financialization proxies are positive and significant. We additionally notice that the effect of banking crises becomes stronger when R\&D and unionization jointly become relevant in our analysis. Unionization is found to be highly significant bearing a negative sign, i.e. reduces income inequality, which is in line with Gordon (2012). Trade unions reduce inequality both by raising wages at the low end and by constraining them at the high end. Western and Rosenfeld (2011) estimate that the decline of labor unions' power in the US economy is responsible for 20 to $33 \%$ of the overall rise in inequality. Also, $\mathrm{R} \& \mathrm{D}$ expenditure is positively associated with rising inequality suggesting that R\&D expenses signal technological improvements which could result in rising incomes, yet in an uneven manner. The latter could indicate a skill-biased technological change as rewards disproportionately flow to highly skilled workers. In this view, educational progress and better schooling should normally be the key solution to containing inequality yet education is again found to be statistically significant and positive.

\section{[Table 4 about here]}

The finding regarding banking crises indicates that historically the financial burden in the aftermath of banking crises falls on taxpayers, mainly affecting lower incomes, thus spurring income inequality. The positive effect of banking crises on inequality is in contrast 
with Agnello and Sousa (2012) who find that a banking crisis reduces inequality n OECD countries but in line with Li and Yu (2014) and Haan and Sturm (2017) who suggest that financial development and banking crises increase income inequality. Furthermore, Atkinson and Morelli (2010) in a study of 25 countries spanning the period 1911 to 2010 provide evidence on patterns of rising inequality that follow systemic banking crises. Their main findings, which are in line with Rajan's hypothesis, suggest that income inequality in the USA was increasing before both the 1929 crash and the recent 2008 financial crisis. They note, however, that this observed pattern is not paramount across other countries. The estimates for credit market regulation, unemployment, and productivity are in line with those reported in Table 3.

Regarding the third inequality measure, the Gini index based on manufacturing pay, the results shown in Table 5, are also interesting and indicate that high unionization and credit market regulation are effective in reducing income inequality. It is worth noting that in the strong presence of negative effects from credit market regulation to inequality, the impact of the financialization proxies is somewhat neutralized with only one of them being significant. The latter finding might indicate that financialization is not a negative phenomenon per se as long as adequate and effective regulation is in place. Finally, the estimates for productivity are consistent with our previous findings, confirming the uneven wage dispersion and diverging productivity growth across economies.

\section{[Table 5 about here]}

Having considered all four different proxies for financialization (deposit money bank assets to deposit money bank assets and central bank assets, private credit by deposit money banks, bank deposits, and domestic credit to the private sector) the evidence suggests that private credit by deposit money banks has a consistent and significant positive effect on income inequality. In particular, when we consider the Gini coefficient based on manufacturing income only private credit remains significant. This puzzling result might be due to: (a) issues relating to the construction of the Gini income inequality index and (b) the diminishing share of manufacturing income as a percentage of total income, i.e. financial income in the form of capital gains, interest and dividends has increased considerably compared to the income generated through traditional economic activity.

By and large, the generated evidence is consistent with Denk and Cazenave-Lacroutz (2015) hence suggesting that financialization is widening income inequality as people with high incomes enjoy unrestricted access to credit vis-à-vis lower income groups who are more likely to be turned down. On a different note, Godechot (2016) finds that the finance sector's 
share of GDP is a significant driver of inequality which when decomposed the volume of stocks traded in national stock exchanges and of shares held as assets in banks' balance sheets are found to be the main factors that drive the entire process. His evidence also suggests that the financialization of nonfinancial firms and households do not appear to exert a significant impact.

As far as credit regulation is concerned the generated evidence is very ambiguous. One interpretation can be that credit regulation is implemented by supervisory authorities to prevent and correct distortions in the credit markets which inevitably leads to more stringent regulations for operational banking procedures. In so far as these procedures are tailored to address corporate governance issues of banking, inequality is not thought to be affected significantly (Delis et al., 2014). A regulatory framework, however, that imposes higher restrictions on lending tends to produce bounded and less competitive markets. As such, it is expected that only well-established firms with sound credit records and high levels of collateral appear to have easier access to credit whereas the relatively weaker firms are severely constrained. Given that tighter regulation and hence, higher supervisory power, provides sound and effective financial-intermediation services, investment opportunities are expected to flourish. The resulting competitive environment will have a positive effect on lower-income households as funds will be allocated to innovative investment ideas. In this context, regulators should take preventive measures to restrict an explosive growth in finance and provide a stable and effective financial system. At the same time, regulators need to preserve the link between finance and real economic activity which will allow equal opportunities in accessing credit and sustaining economic fairness, hence reducing inequality.

\section{Concluding remarks}

This study explores the impact of financialization on income inequality whilst controlling for the effect of banking crises, credit market regulation, and globalization, among other factors. We provide new evidence on the inequality-financialization nexus using alternative proxies for inequality and financialization for a panel of 19 OECD countries during the period 2000-2017. In the disposable income Gini specifications, two out of the four financialization measures turned out to significantly contribute to rising inequality whilst in the market income Gini specifications, three out of the four financialization proxies were found to have exerted an adverse effect on inequality. When a Gini coefficient based on manufacturing pay is considered, all but one of the financialization proxies are insignificant. Furthermore, apart from trade unions which appear to be playing a significant role in reducing inequality in two out of 
the three Gini specifications, the effects of some of the other control variables are somewhat mixed.

Credit regulation is found to convey puzzling signals suggesting that further exploration should be pursued. It is reasonable to assume that banking regulation aims to support the stability of the financial system by absorbing shocks and preventing failures that potentially lead to crises. On the one hand, banking regulatory policies may have a positive effect on the distribution of income but on the other hand, 'too-much' bank regulation may adversely affect the real economy, especially in the long run. Generally speaking, financial regulation purports to enhance the creditworthiness of banks and insulate the financial sector from potential shocks. In this context, numerous studies suggest that regulations affect the banking sector in terms of shaping bank risk (e.g., Laeven and Levine, 2009; Agoraki et al., 2009), bank efficiency (Barth et al., 2010), as well as the frequency of banking crises (e.g., Barth et al., 2008). All in all, the extant literature on the relationship between credit regulation and financial stability remains inconclusive. However, the ambiguous effect observed in this study between credit regulation and income inequality is of particular interest, as its interpretation should be sought in frameworks wherein the role of political economy mechanisms assumes a more prominent role (see for instance Rajan, 1994, 2010 and Stiglitz, 2012).

Furthermore, our results potentially suggest that there are certain aspects of financial activity that promotes increasing income inequality. Whilst credit activities to households and businesses might contribute negligibly to income inequality, other stealth, and more sophisticated activities around financial markets that are difficult to fathom might have a greater impact on inequality. In particular, the way financial markets function allows different actors (such as traders, etc.) to freely move their assets where it is more lucrative for them. Hyper-concentration in the finance sector not only does it increase the systemic risk but also contributes to the constant transfer of income from the productive sectors of the economies to the finance sector. Therefore, measures aimed at either deleveraging the colossal banks or even breaking them up might be needed to keep the sector in a healthy state. Ensuring solvency of the finance sector might require policies for further restructuring or more radical policies that tie the banking sector's profitability to economy-wide growth. After all, governments need banks to channel credit to the productive sectors so that the economy is recharged.

As the literature that looks at the relationship between inequality and financialization keeps growing, there are still conundrums suggesting that it remains an unexplored area with several forces at play. Tackling inequality is a multi-faceted challenge for policymakers as there is growing, yet still blurred evidence of linkages with economic growth and globalization, 
financialization and regulation, and downturns and upswings of the business cycle jointly with the not-so-uncommon occurrences of financial crises especially in advanced economies. Policymakers need to advance policies that foster real economic activity, support trade linkages, and provide employment opportunities to mitigate income inequality. At the same time, regulators should calibrate measures that meaningfully connect finance to the real economic activity but tame speculative behavior in the financial markets. Financial deregulation in conjunction with the growth and development of the global financial markets as well as the magnitude of financial rent expropriated during this process is a compelling case for further exploration.

On the whole, rising income inequality is inextricably linked to rising volatility and uncertainty in advanced economies. In so far as prices of financial assets increase incessantly adding a close-to-nothing value in the real economy, inequality is bound to get worse hence creating a riskier economic environment. The Great Recession, as well as a growing body of research, has shown that financialization has increased inequality. Nonetheless, our results suggest that the subject relationship is not so straightforward and merits further research on the actors and processes at play. 


\section{Appendix}

Table A1. Pesaran (2015) test for cross-sectional dependence

\begin{tabular}{ll}
\hline Variable & Test statistic (p-value) \\
\hline Ginidisp & $10.078^{* * *}(0.000)$ \\
Ginimkt & $24.263 * * *(0.000)$ \\
Ginimp & $8.654 * * *(0.000)$ \\
unemployment & $53.665 * * *(0.000)$ \\
productivity & $55.397 * * *(0.000)$ \\
trade & $18.211^{* * *}(0.000)$ \\
GDPpc & $55.403 * * *(0.000)$ \\
FDI & $11.089^{* * *}(0.000)$ \\
union & $38.977 * * *(0.000)$ \\
R\&D & $14.039^{* * *}(0.000)$ \\
inflation & $43.713 * * *(0.000)$ \\
education & $8.518^{* * *}(0.000)$ \\
credmarkreg & $55.340 * * *(0.000)$ \\
bankcrisis & $16.850^{* * *}(0.000)$ \\
depositassets & $10.522 * * *(0.000)$ \\
privatecredit & $6.672 * * *(0.000)$ \\
bankdeposits & $22.690^{* * *}(0.000)$ \\
domcredpri & $5.394 * * *(0.000)$ \\
\hline
\end{tabular}

Note(s): $* * *$ denotes statistical significance at the $1 \%$ level. 


\section{References}

Agnello, L. and Sousa, R.M. (2012), “How do banking crises impact on income inequality?”, Applied Economic Letters, Vol. 19 No. 15, pp. 1425-1429.

Agnello, L., Mallick, S.K. and Sousa, R.M. (2012), "Financial reforms and income inequality", Economics Letters, Vol. 116 No 3, pp.583-587.

Agoraki, M.E.K., Delis, M.D. and Pasiouras, F. (2011), "Regulations, competition and bank risk-taking in transition countries", Journal of Financial Stability, Vol. 7 No 1, pp.3848.

Alexiou, C. and Nellis, J.G. (2016), "Investment decisions within the context of financialization: Cointegration evidence from the UK economy", Panoeconomicus, Vol. 63 No 1, pp.113-133.

Alvarez, I. (2015), "Financialization, non-financial corporations and income inequality: The case of France", Socio-Economic Review, Vol. 13 No 3, pp.449-475.

Argitis, G. and Pitelis, C. (2001), "Monetary policy and income distribution: Evidence from the USA and the UK", Journal of Post-Keynesian Economics, Vol. 23 No 4, pp.617638.

Argitis, G. and Pitelis, C. (2008), "Global finance and systemic instability”, Contributions to Political Economy, Vol. 27 No 1, pp.1-11.

Assa, J. (2012), "Financialization and its consequences: The OECD experience", Finance Research, Vol 1 No 1, pp.35-39.

Atkinson, A. and Morelli, S. (2010), "Inequality and banking crises: A first look", Report for the International Labour Foundation, International Labour Organization. Available at: https://www.tony-atkinson.com/researchpapers/Atkinson_and_Morelli Inequality and Banking_Crises - A F First_Look.pdf

Barth, J. R., Lin, C., Ma, Y., Seade, J. and Song, F. M. (2010), "Do bank regulation, supervision and monitoring enhance or impede bank Efficiency?", Available at SSRN: http://ssrn.com/abstract=1579352.

Barth, J.R., Caprio, G.J. and Levine, R. (2008), "Bank regulations are changing: But for better or worse?”, Policy Research Working Paper 4646, The World Bank.

Beck, T., Demirgüç-Kunt, A. and Levine, R. (2007), "Finance, inequality and the poor", Journal of Economic Growth, Vol. 12 No 1, pp.27-49.

Bertoli, S. and Farina, F. (2007), "The functional distribution of income: A review of the theoretical literature and of the empirical evidence around its recent pattern", Working 
Paper 5/2007, Department of Economic Policy, Finance and Development University of Siena.

Blanchard, O.J. (1997), “The medium run”, Brookings Papers on Economic Activity, pp.89141.

Bonefeld, W. (1996), "Monetarism and crisis. Bonefeld, W. and Holloway, J. (Ed.), Global capital, national state and the politics of money, Palgrave Macmillan, London, pp. 3568.

Card, D. (1992), "The effects of unions on the distribution of wages: Redistribution or relabelling?" NBER Working Paper 4195, National Bureau of Economic Research.

Cecchetti, S. and Kharroubi, K. (2012), "Reassessing the impact of finance on growth", BIS Working Papers No 381. Bank for International Settlements, Basel, Switzerland.

Claessens, S. and Perotti, E. (2007), "Finance and inequality: Channels and evidence", Journal of Comparative Economics, Vol. 35 No 4, pp.748-773.

Crotty, J. and Epstein, G. (1996), "In defence of capital controls", Socialist Register, Vol. 32 No. 32, pp.118-149.

Crotty, J. (2009), "Structural causes of the global financial crisis: A critical assessment of the 'new financial architecture"”, Cambridge Journal of Economics, Vol. 33 No 4, pp.563580.

Davidson, P. (1978). Money and the Real World, Macmillan, London.

Delis, M.D., Hasan, I. and Kazakis, P. (2014), "Bank regulations and income inequality: empirical evidence", Review of Finance, Vol. 18 No. 5, pp.1811-1846.

Denk, O. and Cournède. B. (2015), "Finance and income inequality in OECD countries", OECD Working Papers No. 1224, Paris, OECD Publishing.

De Vita, G. and Luo, Y. (2020), "Financialization, household debt and income inequality: Empirical evidence", International Journal of Finance and Economics. https://doi.org/10.1002/ijfe.1886

DiNardo, J. and Lemieux, T. (1997), "Diverging male wage inequality in the United States and Canada, 1981-88: Do institutions explain the difference?", Industrial and Labor Relations Review, Vol. 50 (July 1997), pp.629-651.

Driscoll, J.C. and Kraay, A.C. (1998), "Consistent covariance matrix estimation with spatially dependent panel data”, Review of Economics and Statistics, Vol. No 4, pp.549-560.

Dünhaupt, P. (2013), “The effect of financialization on labour's share of income”, Working Paper 17/2013, Institute for International Political Economy. 
Epstein, G. (2001), "Financialization, rentier interests, and central bank policy", Manuscript, Department of Economics, University of Massachusetts, Amherst, MA, December.

Epstein, G. (2005), Financialization and the World Economy, Edward Elgar, Cheltenham.

Epstein, G. (2015), Financialization: There's Something Happening Here, Working Paper 394/15, University of Massachusetts.

Evans, L. (2003), Why the bubble burst: U.S. stock market performance since 1982, Edward Elgar, Northampton, MA.

Fortin, N. and Lemieu, T. (1997), "Institutional changes and rising wage inequality: Is there a linkage?", Journal of Economic Perspectives, Vol. 11, pp.75-96.

Furman, J. and Orszag, P. (2018), "Slower productivity and higher inequality: Are they related?" Working Paper 18-4, Peterson Insitute for International Economics.

Galbraith, J.K. and Kum, H. (2005), "Estimating the inequality of household incomes: A statistical approach to the creation of a dense and consistent global data set" ,Review of Income and Wealth, Vol. 51 No 1, pp.115-143.

Godechot, O. (2016), "Financialization is marketization! A study of the respective impacts of various dimensions of financialization on the increase in global inequality", Sociological Science, Vol. 30 No. 3, pp.495-519.

Gordon, C. (2012), "Union decline and rising inequality in two charts", Economic Policy Institute. Available at: https://www.epi.org/blog/union-decline-rising-inequality$\underline{\text { charts/ }}$

Gosling, A. and Machin. S. (1995), "Trade unions and the dispersion of earnings in British establishments", Oxford Bulletin of Economics and Statistics, Vol. 57 No. 2, pp.16784.

Greenwood, J. and Jovanovic, B. (1990), "Financial development, growth, and the distribution of income", Journal of Political Economy, Vol. 98 No. 5, pp.1076-1107.

Haan, de J. and Sturm, J-E. (2017), "Finance and income inequality: A review and new evidence", European Journal of Political Economy, Vol. 50, pp.171-195.

Harcourt, G. and Sardoni, C. (1995), "The general theory of employment, interest and money: Three views" P. Arestis (Ed.) Keynes Money and the Open Economy: Essays in Honour of Paul Davidson, Edward Elgar, Cheltenham, pp.1-13.

Harvey, D. (2005), A brief history of neoliberalism, Oxford University Press, Oxford.

Harvey, D. (2010), The enigma of capital and the crises of capitalism, Oxford University Press, New York. 
Hilferding, R. (1981), Finance capital: A study of the latest phase of capitalist development, Routledge, London.

International Labour Organization (2009), World of Work Report 2009: The global job crisis and beyond, International Institute for Labour Studies, Geneva. Available at: https://www.ilo.org/wcmsp5/groups/public/---dgreports/---dcomm/--publ/documents/publication/wcms 120079.pdf

Jauch, S. and Watzka, S. (2016), "Financial development and income inequality: A panel data approach”, Empirical Economics, Vol. 51 No. 1, pp.291-314.

Jaumotte, F., Lall, S. and Papageorgiou, C. (2013), "Rising income inequality: Technology, or trade and financial globalization?”, IMF Economic Review, Vol. 61 No, 2, pp.271-309.

Köhler, K., Guschanski, A. and Stockhammer, E. (2018), “The impact of financialisation on the wage share: A theoretical clarification and empirical assessment", Economics Discussion Papers No. 2018-1, School of Economics, Kingston University London.

Krippner, G. R. (2011), Capitalizing on crisis, Harvard University Press, Cambridge.

Kus, B. (2012), "Financialisation and income inequality in OECD Nations: 1995-2007", Economic and Social Review, Vol. 43, pp. 477-499.

Kwon, R. and Roberts, A. (2015), "Financialization and income inequality in the new economy: An exploration of finance's conditional effects", Sociology of Development, Vol. 1 No 4, pp.442-462.

Laeven, L. and Levine, R. (2009), "Bank governance, regulation and risk taking”, Journal of Financial Economics, Vol. 93 No 2, pp.259-275.

Laeven, L. and Valencia, F (2013), "Systemic banking crises database", IMF Economic Review, Vol. 61 No. 2, pp.225-270.

Li, J. and Yu, H. (2014), "Income inequality and financial reform in Asia: The role of human capital”, Applied Economics, Vol 46 No 24, pp.2920-2935.

Lin, K-H. and Tomaskovic-Devey, D. (2013), "Financialization and U.S. income inequality, 1970-2018”, American Journal of Sociology, Vol. 118 No. 50, pp.1284-1329.

Lin, L-H. (2016), “The rise of finance and firm employment dynamics”, Organization Science, Vol. 27 No. 4, pp. 972-988.

McLaughlin, P. and Stanley, L. (2016), “ Regulation and income inequality: The regressive effects of entry regulations", Mercatus Working Paper, George Mason University.

Minsky, H. (1982), Can it happen again?, M. E. Sharpe, New York. 
Minsky, H. (1986), Stabilising an unstable economy, Yale University Press, New Haven.

Orhangazi, O. (2008), Financialization and the US Economy, Edward Elgar, Cheltenham.

Philippon, T. (2007), "Why has the U.S. financial sector grown so much? The role of corporate finance", NBER Working Paper 13405, National Bureau of Economic Research.

Prasad, M. (2005), The politics of free markets: The rise of neoliberal economic policies in Britain, France, Germany, and the United States, University of Chicago Press, Chicago.

Rajan, R.G. (1994), "Why bank credit policies fluctuate: A theory and some evidence", The Quarterly Journal of Economics, Vol. 109 No. 2, pp.399-441.

Rajan, R.G. (2010), Fault lines, Princeton University Press, Princeton.

Ramos, G. (2016), "The productivity and equality nexus". OECD Forum. http://www.oecd.org/social/productivity-equality-nexus.htm

Sawyer, M. (2015), "Financialization, financial structures, economic performance and employment", FESSUD Working Paper No. 93.

Sawyer, M. (2017), "Financialization and the economy", A. Gemzik-Salwach and K. Opolski (Eds.), Financialization and the economy, Routledge, London.

Solt, F. (2020), "Measuring income inequality across countries and over time: The standardized world income inequality database”, Social Science Quarterly, Vol. 101 No 3, pp. 11831199. SWIID Version 8.3.

Stiglitz, J.E. (2012), The price of inequality: How today's divided society endangers our future, W. W. Norton, Princeton.

Szopa, A. (2017), "Financial risk and financialization", A. Gemzik-Salwach and K. Opolski (Eds.), Financialization and the economy, Routledge, London.

Tomaskovic-Devey, D. and Lin, K.H. (2011), "Income dynamics, economic rents, and the financialization of the US economy", American Sociological Review, Vol. 76 No. 4, pp.538-559.

Tomaskovic-Devey, D., Lin, K.H. and Meyers, N. (2015), "Did financialization reduce economic growth?" Socio-Economic Review, Vol. 13 No. 3, pp.525-548.

Van Arnum, B.M. and Naples, M.I. (2013), "Financialization and income inequality in the United States, 1967-2010”, American Journal of Economics and Sociology, Vol. 72 No. 5, pp.1158-1182. 
Western, B. and Rosenfeld, J. (2011), "Unions, norms, and the rise in U.S. wage inequality", American Sociological Review, Vol. 76 No. 4, pp.513-537.

Willen, P., Hendel, I. and Shapiro, J. (2004), "Educational opportunity and income inequality", NBER Working Paper 10879, National Bureau of Economic Research.

Wright, E-O and Rogers, J. (2015), American Society: How It Really Works, W.W. Norton, New York.

Zalewski, D. and Whalen, C. (2010), "Financialization and income inequality: A post Keynesian institutionalist analysis”, Journal of Economic Issues, Vol. 44 No. 3, pp.757777. 


\section{Tables}

Table 1.

Description of variables

\begin{tabular}{|c|c|c|}
\hline Variables & Definition & Source \\
\hline Ginidisp & $\begin{array}{l}\text { Gini index of inequality based on household } \\
\text { disposable income (post-tax, post-transfer) }\end{array}$ & $\begin{array}{l}\text { Standardized World Income } \\
\text { Inequality Database } 8.3 \text {, Solt } \\
\text { (2020) } \\
\text { https://fsolt.org/swiid// }\end{array}$ \\
\hline Ginimkt & $\begin{array}{l}\text { Gini index of inequality based on household market } \\
\text { income (pre-tax, pre-transfer) }\end{array}$ & $\begin{array}{l}\text { Standardized World Income } \\
\text { Inequality Database } 8.3 \text {, Solt } \\
(2020)\end{array}$ \\
\hline Ginimp & $\begin{array}{l}\text { Gini index of inequality based on manufacturing pay } \\
\text { (available only for 2000-2015) }\end{array}$ & 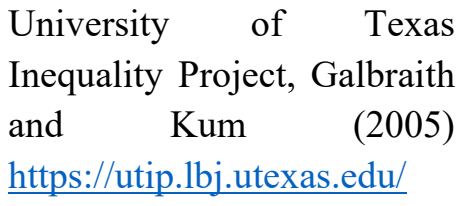 \\
\hline unemployment & Unemployment (\% of total labor force) & $\begin{array}{l}\text { World Development } \\
\text { Indicators, World Bank }\end{array}$ \\
\hline productivity & Productivity (GDP per hour worked) & $\begin{array}{l}\text { Compendium of Productivity } \\
\text { Indicators, OECD }\end{array}$ \\
\hline trade & $\begin{array}{l}\text { Sum of exports and imports of goods and services } \\
(\% \text { of GDP) }\end{array}$ & $\begin{array}{l}\text { World Development } \\
\text { Indicators, World Bank }\end{array}$ \\
\hline GDPpc & Gross domestic product per capita (US dollars) & Economic Outlook, OECD \\
\hline$F D I$ & Foreign direct investment net inflows (\% of GDP) & $\begin{array}{l}\text { World Development } \\
\text { Indicators, World Bank }\end{array}$ \\
\hline union & $\begin{array}{l}\text { Union density: The ratio of wage and salary earners } \\
\text { that are trade union members divided by the total } \\
\text { number of wage and salary earners. }\end{array}$ & $\begin{array}{l}\text { Employment and Labour } \\
\text { Markets statistics, OECD }\end{array}$ \\
\hline$R \& D$ & Research and development expenditure (\% of GDP) & $\begin{array}{l}\text { World Development } \\
\text { Indicators, World Bank }\end{array}$ \\
\hline inflation & Inflation $(\%)$ & $\begin{array}{l}\text { World Development } \\
\text { Indicators, World Bank }\end{array}$ \\
\hline education & School enrollment, secondary (\% gross) & World Bank \\
\hline credmarkreg & $\begin{array}{l}\text { Credit market regulation index (scale } 0-10 \text { ): This } \\
\text { index reflects regulatory restraints that limit the } \\
\text { freedom of exchange in credit markets and is the } \\
\text { average of three sub-component ratings: a) an index } \\
\text { that depicts the extent to which the banking industry } \\
\text { is privately owned, b) an index about the extent to } \\
\text { which credit is supplied to the private sector, and c) } \\
\text { an index about whether controls on interest rates } \\
\text { interfere with the credit market. }\end{array}$ & $\begin{array}{lr}\text { Economic } & \text { Freedom Index, } \\
\text { Frazier } & \text { Institute, } \\
\text { https://www.fraserinstitute.o } \\
\mathrm{rg} /\end{array}$ \\
\hline bankcrisis & $\begin{array}{l}\text { Banking crisis dummy that takes the value } 1 \text { for a } \\
\text { banking crisis and } 0 \text { otherwise). According to } \\
\text { Laeven and Valencia ( } 2013, p \text { 228) a banking crisis } \\
\text { is defined as systemic if there are significant signs of }\end{array}$ & $\begin{array}{lr}\text { Global } & \text { Financial } \\
\text { Development } & \text { Database, } \\
\text { World } & \text { Bank, } \\
\text { https://www.worldbank.org/ }\end{array}$ \\
\hline
\end{tabular}


financial distress in the banking system (bank runs, losses in the banking system, and/or bank liquidations), and there is significant banking policy intervention measures in response to significant losses in the banking system.

depositassets Deposit money bank assets as a share of the sum of deposit money bank and central bank claims on domestic nonfinancial real sector (\%) where deposit money banks comprise commercial banks and other financial institutions that accept transferable deposits, such as demand deposits while assets include claims on domestic real nonfinancial sector which includes central, state and local governments, nonfinancial public enterprises and private sector.

privatecredit Private credit by deposit money banks (\% of GDP): Financial resources provided to the private sector by domestic money banks where domestic money banks comprise commercial banks and other financial institutions that accept transferable deposits, such as demand deposits.

bankdeposits

domcredpri
Bank deposits ( $\%$ of GDP): The total value of demand, time and saving deposits at domestic deposit money banks where deposit money banks comprise commercial banks and other financial institutions that accept transferable deposits, such as demand deposits.

Domestic credit to private sector ( $\%$ of GDP) Financial resources provided to the private sector, such as through loans, purchases of nonequity securities, and trade credits and other accounts receivable, that establish a claim for repayment. en/publication/gfdr/data/glob al-financial-development-

database

$\begin{array}{ll}\text { Global } & \text { Financial } \\ \text { Development } & \text { Database, }\end{array}$

World Bank

Global Financial

Development Database,

World Bank

Global Financial

Development Database,

World Bank

Global

Financial

Development Database, 
Table 2.

Summary statistics

\begin{tabular}{llllll}
\hline Variable & Obs. & Mean & St. Dev. & Min & Max \\
\hline Ginidisp & 340 & 29.41 & 3.57 & 22.40 & 38.20 \\
Ginimkt & 340 & 46.70 & 4.23 & 32.40 & 53.90 \\
Ginimp & 278 & 37.83 & 2.85 & 30.53 & 44.50 \\
unemployment & 342 & 6.581 & 3.32 & 2.100 & 26.09 \\
productivity & 342 & 98.11 & 6.59 & 62.91 & 117.3 \\
trade & 339 & 75.26 & 32.76 & 19.80 & 169.4 \\
GDPpc & 342 & 38,744 & 9,412 & 18,083 & 67,051 \\
FDI & 340 & 4.27 & 8.26 & -8.014 & 87.44 \\
union & 303 & 31.75 & 20.82 & 7.794 & 79.00 \\
R\&D & 290 & 2.28 & 0.76 & 0.88 & 4.28 \\
inflation & 342 & 1.752 & 1.16 & -1.35 & 4.67 \\
education & 287 & 112.8 & 17.51 & 91.96 & 163.9 \\
credmarkreg & 342 & 9.312 & 0.72 & 6.85 & 10 \\
bankcrisis & 342 & 0.12 & 0.32 & 0 & 1 \\
depositassets & 324 & 97.03 & 5.25 & 68.21 & 100.00 \\
privatecredit & 319 & 106.1 & 34.98 & 37.84 & 211.9 \\
bankdeposits & 300 & 85.75 & 37.98 & 39.38 & 221.0 \\
domcredpri & 328 & 121.8 & 38.09 & 40.22 & 212.3 \\
\hline
\end{tabular}


Table 3.

Dependent variable Gini index of inequality based on household disposable income

\begin{tabular}{|c|c|c|c|c|}
\hline & Model 1 & Model 2 & Model 3 & Model 4 \\
\hline \multirow[t]{2}{*}{ unemployment } & $0.098 * * *$ & $0.087 * * *$ & $0.088 * * *$ & $0.090 * * *$ \\
\hline & $(0.021)$ & $(0.025)$ & $(0.026)$ & $(0.024)$ \\
\hline \multirow[t]{2}{*}{ productivity } & $0.076 * * *$ & $0.083 * * *$ & $0.083 * * *$ & $0.081 * * *$ \\
\hline & $(0.023)$ & $(0.023)$ & $(0.021)$ & $(0.023)$ \\
\hline \multirow[t]{2}{*}{ trade } & 0.002 & 0.002 & -0.005 & 0.003 \\
\hline & $(0.007)$ & $(0.007)$ & $(0.007)$ & $(0.007)$ \\
\hline \multirow[t]{2}{*}{$\triangle \ln G D P p c$} & -0.490 & -0.449 & -0.164 & -0.535 \\
\hline & $(1.471)$ & (1.393) & (1.409) & (1.338) \\
\hline \multirow[t]{2}{*}{$F D I$} & -0.002 & -0.003 & -0.001 & -0.003 \\
\hline & $(0.004)$ & $(0.004)$ & $(0.004)$ & $(0.005)$ \\
\hline \multirow[t]{2}{*}{ union } & -0.026 & -0.017 & -0.024 & -0.018 \\
\hline & $(0.025)$ & $(0.034)$ & $(0.032)$ & $(0.033)$ \\
\hline \multirow[t]{2}{*}{$R \& D$} & 0.346 & 0.300 & 0.217 & 0.287 \\
\hline & $(0.200)$ & $(0.175)$ & $(0.153)$ & $(0.163)$ \\
\hline \multirow[t]{2}{*}{ inflation } & -0.047 & -0.046 & 0.002 & -0.046 \\
\hline & $(0.041)$ & $(0.038)$ & $(0.042)$ & $(0.040)$ \\
\hline \multirow[t]{2}{*}{ education } & 0.008 & $0.007 * *$ & $0.007 * *$ & $0.007 * *$ \\
\hline & $(0.004)$ & $(0.003)$ & $(0.003)$ & $(0.003)$ \\
\hline \multirow[t]{2}{*}{ credmarkreg } & $0.380 * * *$ & $0.383 * * *$ & $0.225^{* *}$ & $0.379 * * *$ \\
\hline & $(0.092)$ & $(0.093)$ & $(0.081)$ & $(0.099)$ \\
\hline \multirow[t]{2}{*}{ bankcrisis } & $0.269 * *$ & 0.182 & 0.141 & $0.184 * *$ \\
\hline & $(0.111)$ & $(0.087)$ & $(0.105)$ & $(0.081)$ \\
\hline \multirow[t]{2}{*}{ depositassets } & -0.021 & & & \\
\hline & $(0.011)$ & & & \\
\hline \multirow[t]{2}{*}{ privatecredit } & & $0.004 * *$ & & \\
\hline & & $(0.002)$ & & \\
\hline \multirow[t]{2}{*}{ bankdeposits } & & & 0.011 & \\
\hline & & & $(0.006)$ & \\
\hline \multirow[t]{2}{*}{ domcredpri } & & & & $0.005 * * *$ \\
\hline & & & & $(0.001)$ \\
\hline \multirow[t]{2}{*}{ Constant } & $18.556 * * *$ & $15.288 * * *$ & $16.783 * * *$ & $15.397 * * *$ \\
\hline & $(3.214)$ & $(2.745)$ & $(2.417)$ & $(2.788)$ \\
\hline Observations & 218 & 222 & 207 & 222 \\
\hline $\mathrm{R}^{2}$ within & 0.553 & 0.553 & 0.586 & 0.556 \\
\hline
\end{tabular}

Note(s): Driscoll and Kraay's (1998) robust standard errors are given in parentheses. $* * *$ and $* *$ denote statistical significance at the 1 and $5 \%$ level, respectively. 
Table 4.

Dependent variable Gini index of inequality based on household market income

\begin{tabular}{|c|c|c|c|c|}
\hline & Model 1 & Model 2 & Model 3 & Model 4 \\
\hline \multirow[t]{2}{*}{ unemployment } & $0.281 * * *$ & $0.266 * * *$ & $0.282 * * *$ & $0.277 * * *$ \\
\hline & $(0.025)$ & $(0.025)$ & $(0.028)$ & $(0.024)$ \\
\hline \multirow[t]{2}{*}{ productivity } & $0.126 * * *$ & $0.121 * * *$ & $0.118 * * *$ & $0.119 * * *$ \\
\hline & $(0.018)$ & $(0.020)$ & $(0.021)$ & $(0.020)$ \\
\hline \multirow[t]{2}{*}{ trade } & -0.009 & -0.006 & -0.015 & -0.006 \\
\hline & $(0.009)$ & $(0.010)$ & $(0.009)$ & $(0.010)$ \\
\hline \multirow[t]{2}{*}{$\triangle \ln G D P p c$} & 0.649 & 1.188 & 1.708 & 0.878 \\
\hline & (1.858) & $(1.552)$ & (1.948) & $(1.561)$ \\
\hline \multirow[t]{2}{*}{$F D I$} & -0.006 & -0.007 & -0.006 & -0.006 \\
\hline & $(0.006)$ & $(0.006)$ & $(0.006)$ & $(0.007)$ \\
\hline \multirow{2}{*}{ union } & $-0.087 * * *$ & $-0.081 * *$ & $-0.092 * * *$ & $-0.089 * *$ \\
\hline & $(0.025)$ & $(0.033)$ & $(0.028)$ & $(0.032)$ \\
\hline \multirow[t]{2}{*}{$R \& D$} & $1.504 * * *$ & $1.446 * * *$ & $1.375 * * *$ & $1.425 * * *$ \\
\hline & $(0.228)$ & $(0.224)$ & $(0.184)$ & $(0.216)$ \\
\hline \multirow[t]{2}{*}{ inflation } & -0.046 & -0.050 & -0.003 & -0.045 \\
\hline & $(0.056)$ & $(0.052)$ & $(0.064)$ & $(0.055)$ \\
\hline \multirow[t]{2}{*}{ education } & $0.022 * * *$ & $0.020 * * *$ & $0.020 * * *$ & $0.019 * * *$ \\
\hline & $(0.005)$ & $(0.003)$ & $(0.003)$ & $(0.003)$ \\
\hline \multirow[t]{2}{*}{ credmarkreg } & $0.638 * * *$ & $0.650 * * *$ & $0.654 * * *$ & $0.641 * * *$ \\
\hline & $(0.183)$ & $(0.172)$ & $(0.158)$ & $(0.180)$ \\
\hline \multirow[t]{2}{*}{ bankcrisis } & $0.387 * *$ & $0.255^{* *}$ & $0.257 * *$ & $0.288 * *$ \\
\hline & $(0.153)$ & $(0.118)$ & $(0.118)$ & $(0.118)$ \\
\hline \multirow[t]{2}{*}{ depositassets } & -0.005 & & & \\
\hline & $(0.014)$ & & & \\
\hline \multirow[t]{2}{*}{ privatecredit } & & $0.010 * * *$ & & \\
\hline & & $(0.002)$ & & \\
\hline \multirow[t]{2}{*}{ bankdeposits } & & & $0.019 * *$ & \\
\hline & & & $(0.007)$ & \\
\hline \multirow[t]{2}{*}{ domcredpri } & & & & $0.008 * *$ \\
\hline & & & & $(0.003)$ \\
\hline \multirow[t]{2}{*}{ Constant } & $25.799 * * *$ & $24.795 * * *$ & $25.047 * * *$ & $25.353 * * *$ \\
\hline & $(2.418)$ & $(2.940)$ & $(2.792)$ & $(2.965)$ \\
\hline Observations & 218 & 222 & 207 & 222 \\
\hline $\mathrm{R}^{2}$ within & 0.797 & 0.805 & 0.816 & 0.802 \\
\hline
\end{tabular}

Note(s): Please see notes Table 3. 
Table 5.

Dependent variable Gini index of inequality based on manufacturing pay

\begin{tabular}{|c|c|c|c|c|}
\hline & Model 1 & Model 2 & Model 3 & Model 4 \\
\hline \multirow[t]{2}{*}{ unemployment } & 0.074 & 0.039 & $0.073 * *$ & 0.058 \\
\hline & $(0.038)$ & $(0.037)$ & $(0.027)$ & $(0.031)$ \\
\hline \multirow[t]{2}{*}{ productivity } & $0.067 * *$ & $0.059 * * *$ & $0.063 * * *$ & $0.060 * * *$ \\
\hline & $(0.025)$ & $(0.008)$ & $(0.011)$ & $(0.009)$ \\
\hline \multirow[t]{2}{*}{ trade } & -0.000 & 0.004 & 0.002 & 0.002 \\
\hline & $(0.016)$ & $(0.018)$ & $(0.017)$ & $(0.018)$ \\
\hline \multirow[t]{2}{*}{$\triangle \ln G D P p c$} & -0.965 & 0.227 & -0.623 & -0.357 \\
\hline & $(2.055)$ & (2.107) & (1.834) & (2.033) \\
\hline \multirow[t]{2}{*}{$F D I$} & 0.008 & 0.007 & 0.007 & 0.008 \\
\hline & $(0.012)$ & $(0.011)$ & $(0.012)$ & $(0.012)$ \\
\hline \multirow{2}{*}{ union } & $-0.141 * *$ & $-0.101 * * *$ & $-0.112 * * *$ & $-0.115 * * *$ \\
\hline & $(0.049)$ & $(0.032)$ & $(0.030)$ & $(0.030)$ \\
\hline \multirow[t]{2}{*}{$R \& D$} & 0.282 & 0.351 & 0.334 & 0.335 \\
\hline & $(0.741)$ & $(0.655)$ & $(0.749)$ & $(0.702)$ \\
\hline \multirow[t]{2}{*}{ inflation } & -0.045 & -0.073 & -0.080 & -0.064 \\
\hline & $(0.086)$ & $(0.064)$ & $(0.079)$ & $(0.072)$ \\
\hline \multirow[t]{2}{*}{ education } & -0.004 & 0.002 & -0.004 & 0.001 \\
\hline & $(0.010)$ & $(0.008)$ & $(0.008)$ & $(0.009)$ \\
\hline \multirow[t]{2}{*}{ credmarkreg } & $-0.498 * * *$ & $-0.482 * * *$ & $-0.334 * * *$ & $-0.501 * * *$ \\
\hline & $(0.073)$ & $(0.084)$ & $(0.112)$ & $(0.078)$ \\
\hline \multirow[t]{2}{*}{ bankcrisis } & -0.136 & $-0.280^{*}$ & -0.143 & -0.203 \\
\hline & $(0.120)$ & $(0.141)$ & $(0.131)$ & $(0.136)$ \\
\hline \multirow[t]{2}{*}{ depositassets } & 0.023 & & & \\
\hline & $(0.033)$ & & & \\
\hline \multirow[t]{2}{*}{ privatecredit } & & $0.012 * * *$ & & \\
\hline & & $(0.004)$ & & \\
\hline \multirow[t]{2}{*}{ bankdeposits } & & & 0.004 & \\
\hline & & & $(0.011)$ & \\
\hline \multirow[t]{2}{*}{ domcredpri } & & & & 0.006 \\
\hline & & & & $(0.005)$ \\
\hline \multirow[t]{2}{*}{ Constant } & $37.796 * * *$ & $37.235 * * *$ & $37.538 * * *$ & $38.444 * * *$ \\
\hline & $(6.022)$ & $(1.377)$ & $(1.571)$ & $(1.354)$ \\
\hline Observations & 202 & 206 & 192 & 206 \\
\hline $\mathrm{R}^{2}$ within & 0.524 & 0.537 & 0.474 & 0.519 \\
\hline
\end{tabular}

Notes: Please see notes Table 3. 